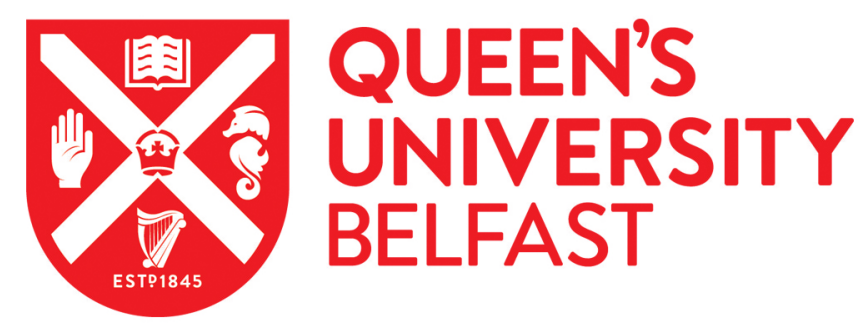

\title{
Effects of cigarette butts on marine keystone species (Ulva lactuca L. and Mytilus edulis L.) and sediment microphytobenthos
}

Green, D. S., Kregting, L., \& Boots, B. (2021). Effects of cigarette butts on marine keystone species (Ulva lactuca L. and Mytilus edulis L.) and sediment microphytobenthos. Marine Pollution Bulletin, 165, [112152]. https://doi.org/10.1016/j.marpolbul.2021.112152

Published in:

Marine Pollution Bulletin

Document Version:

Peer reviewed version

Queen's University Belfast - Research Portal:

Link to publication record in Queen's University Belfast Research Portal

Publisher rights

Copyright 2021 Elsevier Ltd.

This manuscript is distributed under a Creative Commons Attribution-NonCommercial-NoDerivs License

(https://creativecommons.org/licenses/by-nc-nd/4.0/), which permits distribution and reproduction for non-commercial purposes, provided the author and source are cited.

\section{General rights}

Copyright for the publications made accessible via the Queen's University Belfast Research Portal is retained by the author(s) and / or other copyright owners and it is a condition of accessing these publications that users recognise and abide by the legal requirements associated with these rights.

Take down policy

The Research Portal is Queen's institutional repository that provides access to Queen's research output. Every effort has been made to ensure that content in the Research Portal does not infringe any person's rights, or applicable UK laws. If you discover content in the Research Portal that you believe breaches copyright or violates any law, please contact openaccess@qub.ac.uk. 
1 Effects of cigarette butts on marine keystone species (Ulva lactuca L. and Mytilus edulis

$2 \quad$ L.) and sediment microphytobenthos

3 Dannielle Senga Green ${ }^{1}$, Louise Kregting ${ }^{2}$, Bas Boots ${ }^{1}$

$4{ }^{1}$ Applied Ecology Research Group, School of Life Sciences, Anglia Ruskin University, 5 Cambridge, CB1 1PT, United Kingdom.

$6 \quad{ }^{2}$ School of Natural and Built Environment, Queen's University Belfast, Queen's Marine

7 Laboratory, 12-13 The Strand, Portaferry, Northern Ireland, UK.

9 Abstract

10 Outdoor mesocosms with constantly flowing natural seawater were used to test the effects of

11 littered cigarette butts on the filter feeder Mytilus edulis (blue mussel), the macroalga, Ulva

12 lactuca (sea lettuce) and sediment microphytobenthos in a semi-natural marine setting. Either conventional, cellulose acetate, or biodegradable, cellulose, smoked cigarette butts were added at densities of 0.25 or 1 butt $\mathrm{L}^{-1}$. The clearance rates of mussels exposed to 1 butt $\mathrm{L}^{-1}$ of cellulose acetate butts were three times less than the controls. The growth of $U$. lactuca was not measurably affected by cigarette butts, however the sediment chlorophyll content was significantly less in mesocosms exposed to 0.25 and 1 butt $\mathrm{L}^{-1}$ of cellulose acetate butts. These effects occurred despite constant replacement of seawater indicating how hazardous conventional cigarette butts are to marine life. Biodegradable cellulose cigarette butts had minimal effects on the measured variables but should still not be discarded as litter.

22 Key words: smoking, cellulose acetate, green butts, biodegradable, single use plastics, hazardous. 


\section{Introduction}

Global consumption of cigarettes has been rising steadily for years and tobacco consumption is currently considered a global epidemic by the World Health Organization (WHO 2019). In 2016, 5.7 trillion cigarettes were smoked worldwide and it is predicted that by 2025 at least 9 trillion cigarettes will be smoked annually worldwide (Araujo and Costa, 2019). With the majority of smokers littering their used filters (i.e. cigarette butts) ( 75\%; Patel et al. 2013), it is not surprising that they have maintained their position as the most abundant litter item found in beach cleans for over 30 years (Ocean Conservancy 2019). They are difficult to collect as litter, especially due to their small size, and many remain in the environment even after organised litter picking events (Loizidou et al. 2018). Tourist holiday locations are particularly prone to cigarette litter with densities up to 13.3 butts $\mathrm{m}^{-2}$ on beaches in Thailand (Kungskulniti et al. 2018) and a mean of 8 butts $\mathrm{m}^{-2}$ on a beach in Uruguay (Rodríguez et al. 2020). Cigarette butts are also one of the most common litter items caught by floating litter collection devices used in marinas and harbours (Seabins ${ }^{\mathrm{TM}}$, The Seabin Project 2020). For example, they account for $\sim 29 \%$ of all litter collected by Seabins ${ }^{\mathrm{TM}}$ in France (Plastics Europe 2019). Once washed or thrown into water, cigarette butts are only buoyant on the water surface for a short time before they sink (Rech et al, 2014), potentially to be washed back onto shore or further out to sea via waves or currents (Roman et al. 2020). Recently, a citizen-science program: "Dive Against Debris ${ }^{\circledR}$, , found that cigarette butts were the second most common single use plastic item found on the Mediterranean seafloor (at <30 m depth); accounting for 5.14\% and cigar tips $3.4 \%$ of total debris (Consoli et al. 2020).

The majority ( $90 \%$; Pauly et al. 2002) of cigarette filters are still composed of cellulose acetateand are not readily biodegradable $(<15 \%$ weight loss per year in seawater; Gerritse et al. 2020), but can fragment and persist as micro- or nano- sized plastic fibres (Chevalier et al. 2018). Even clean, unsmoked cellulose acetate cigarette filters can cause detrimental effects on 
plants (Green et al. 2019), marine and freshwater fish (Slaughter et al. 2011) and amphibians (Lawal and Ologundudu 2013). Once smoked, however, cigarette butts present a greater risk to the environment than unsmoked filters due to thousands of chemicals including, for example, nicotine, polycyclic aromatic hydrocarbons and heavy metals which are retained in the butt and can leach into the water (Moerman and Potts 2011; Roder Green et al. 2014; Dobaradaran et al. 2019; Dilip et al. 2021). Such leachate has been found to be lethal for marine fish (Slaughter et al. 2011) and gastropods (Booth et al. 2015).

In response to concerns about plastic cigarette filters, alternative filters, composed of pure cellulose have arrived on the market. Alternative cellulose filters have been described as "green", "biodegradable" and "environmentally friendly" implying they would be benign as litter (Amos et al. 2017). A recent experiment, however, found that leachate derived from cellulose cigarette butts had the same detrimental effects on freshwater invertebrates as leachate derived from cellulose acetate cigarette butts (Green et al. 2020). The comparative effects of cellulose acetate versus cellulose cigarette butts have not yet been tested in a marine system. Indeed, despite their prevalence as litter, the effects of any type of cigarette butt on benthic marine organisms has seldom been tested. Of the few studies carried out on benthic marine organisms, lethal effects have been found on gastropods (Austrocochlea porcata, Nerita atramentosa and Bembicium nanum exposed to 5 butts $\mathrm{L}^{-1}$; Booth et al. 2015), sublethal behavioural (when exposed to leachate from $4-8$ butts $\mathrm{L}^{-1}$ ) and genotoxic (when exposed to leachate from 8 butts $\mathrm{L}^{-1}$ ) effects on polychaetes (Hediste diversicolor; Wright et al. 2015) and alterations to microbial assemblages (exposed to 25 butts L ${ }^{-1}$; Quéméneur et al. 2020). These experiments, however, were conducted using highly controlled, closed aquatic systems which did not simulate the continuous flow and replacement of seawater that occurs in the marine environment. 
The aim of the current study was to assess the impacts of conventional versus alternative smoked cigarette filters (butts) in a model benthic habitat with flowing seawater by examining physiological responses of the benthic filter feeder Mytilus edulis Linnaeus (1753) (blue mussel), the primary producer Ulva lactuca Linnaeus (1758) (sea lettuce) and sediment microphytobenthos. It was hypothesised that butts made of cellulose and cellulose acetate would have similar, but negative (i.e. reducing) effects on the clearance rate and attachment strength of $M$. edulis, growth rate of $U$. lactuca and the concentration of chlorophyll- $a$ and $-c$ as a proxy for the sediment microphytobenthos.

\section{Material and methods}

\subsection{Preparation of cigarette butts.}

Cigarettes were rolled by hand using standard, bleached cigarette papers (Rizla, Bristol, UK) filled with an average ( \pm S.E.) of $0.543 \pm 0.002 \mathrm{~g}$ per cigarette of a leading brand of tobacco. Cigarettes contained either a cellulose acetate (slim size; $5 \mathrm{~mm}$ diameter x $14 \mathrm{~mm}$ length) or a cellulose (unbleached) filter (slim size; $6 \mathrm{~mm}$ diameter x $15 \mathrm{~mm}$ length). All cigarettes were smoked using a hand-operated vacuum pump in a fume cabinet with silicone tubing attached to the filter of the cigarettes. After lighting, approximately $30 \pm 1 \mathrm{~mL}$ of air was drawn into each artificial "breath" and each cigarette was smoked for a total inhalation volume of $\sim 600$ $\mathrm{mL}$ per cigarette, thereby emulating a similar total inhalation volume smoked by humans (549 \pm 166 to $585 \pm 245 \mathrm{~mL}$; McBride et al. 1984). Cigarette butts were added to mesocosms 24 28 hours after smoking.

\subsection{Experimental design and mesocosm set-up.}

The experiment consisted of an asymmetric design with 2 fixed factors; Butts (2 levels; cellulose versus cellulose acetate) and Concentration (2 levels; 0.25 and 1 butt $\mathrm{L}^{-1}$ equivalents). A single Control treatment was also included which consisted of no added butts. Each of the 
five treatments was replicated using 6 separate mesocosms $(n=6, N=30)$. The experiment was carried out in an outdoor mesocosm system at the Queen's University Marine Laboratory (QML), Portaferry, Northern Ireland, with natural light conditions (unenclosed system with no roof) and continuously through-flowing, sand filtered seawater pumped from the adjacent Strangford Lough. Mesocosms consisted of opaque polypropylene buckets with a $10 \mathrm{~L}$ capacity (height $=25 \mathrm{~cm}$, diameter $=25 \mathrm{~cm}$ ), each filled up to $3 \mathrm{~cm}$ depth with clean coarse sand (autoclaved, median grain size $500-1000 \mu \mathrm{m}$ ) and to a volume of $8 \mathrm{~L}$ with seawater and left open at the top to ensure full natural light availability. Five individual Mytilus edulis (blue mussel) with an average ( \pm S.E.) length of $45.6 \pm 0.2 \mathrm{~mm}$ and wet biomass of $14.17 \pm 0.22 \mathrm{~g}$ were added to each mesocosm onto a square, $25 \mathrm{~cm}^{2}$ slate settlement plate. Mussels were sourced from Strangford Lough and were acclimatised to the QML outdoor mesocosm system for $>3$ months before being used in the experiment. In addition, one individual Ulva lactuca (sea lettuce) was added to each mesocosm with an average wet biomass of $4.63 \pm 0.04 \mathrm{~g}$ and secured to a pebble using a piece of cotton string in order to simulate how they were found in the field attached to the substratum. Ulva lactuca had been collected from the shore outside QML and maintained within separate outdoor flow-through seawater tanks, for a period of 48 hours prior to commencement of the experiments. When in the mesocosm, M. edulis were fed every 2 days throughout the experiment with $100 \mathrm{~mL}$ of $\sim 5 \times 10^{5}$ cells $\mathrm{mL}^{-1}$ of the microalga Nannochloris atomus. The mesocosms were allowed to settle for 48 hours before introduction of any cigarette butts, and on day 1 of the experiment, treatments were randomly assigned to mesocosms and corresponding butts were added by dropping them onto the surface of the water. Most ( 90\%) butts sank immediately to the sediment, but some remained floating at the surface for up to 2 hours before sinking. Throughout the experiment, the water in the mesocosms was $\sim 10^{\circ} \mathrm{C}$ with a $\mathrm{pH}$ of $\sim 8.2$ and salinity of $\sim 33 \mathrm{ppt}$ and was continuously being replaced via individual hoses at a rate of $\sim 500 \mathrm{~mL} \mathrm{~min}^{-1}$ meaning that the water was completely 
replaced $>3$ times per hour. Each mesocosm was a completely independent replicate and wastewater discharged from mesocosms could not leak into any other mesocosm, with a mesh on their outlet to prevent the butts from being inadvertently removed from the mesocosms. In this way, butts were retained within the mesocosms and were added only once.

\subsection{Measuring responses of $\mathrm{M}$. edulis exposed to cigarette butts.}

After 5 days of exposure in the outdoor mesocosms, clearance rates were estimated using one individual M. edulis from each mesocosm. M. edulis were held in separate $500 \mathrm{~mL}$ glass beakers with an air bubbler and clean sand filtered seawater containing $~ 5 \times 10^{4}$ cells $\mathrm{mL}^{-1}$ of the microalga $N$. atomus. M. edulis began filtering almost immediately and samples of $5 \mathrm{~mL}$ were taken after 0,20 , and $40 \mathrm{~min}$ and algal cells were counted using a haemocytometer. This time length was chosen because it is below the saturation reduction level for M. edulis whereby clearance is reduced when feeding for $>2$ hours at $3 \times 10^{4}$ or more cells ml ${ }^{-1}$ (Pascoe et al. 2009). The dry biomass of each individual M. edulis used in the clearance rates was determined by drying at $60^{\circ} \mathrm{C}$ for 24 hours and weighing to the nearest $\mu \mathrm{g}$. Clearance rates were expressed as litres of water cleared $\mathrm{h}^{-1} \mathrm{~g}^{-1}$ dry weight.

Tenacity (or attachment strength) of one mussel per mesocosm was measured after 5 days of exposure using a portable dynometer (Pesola, Sweden) scaled 0-10 $\mathrm{N}$ to measure the maximal vertical force required for the individual to become dislodged (attachment strength, N). The dynometer had a small clamp attached to it that gripped individual mussels laterally without displacing them. The maximum dislodgement force to the nearest $0.1 \mathrm{~N}$ was recorded for one mussel from each mesocosm. The surface area of each mussel was approximated to an ellipse using height and width (measured with Vernier callipers to $1 \mathrm{~mm}$ ) as major and minor axes (Bell and Gosline 1997). Tenacity is expressed as dislodgement force (N) per unit mussel area $\left(\mathrm{cm}^{-2}\right)$. 
151 After 10 days, each individual U. lactuca was removed and spun dry with a handheld centrifuge for $30 \mathrm{~s}$ before weighing fresh biomass to the nearest $0.01 \mathrm{~g}$. Growth rates were calculated as the increase in biomass between days 0 and 10 .

154 The biomass of the microphytobenthos (MPB) was estimated after 10 days by chlorophyll extraction. Approximately the top $1 \mathrm{~cm}$ of oxic sediment of was sampled and wrapped in tin foil to protect from the sunlight. Chlorophyll was extracted immediately for 1 hour under constant shaking at room temperature in the dark after adding $10 \mathrm{~mL}$ of $90 \%$ acetone to $\sim 1 \mathrm{~g}$ of wet, homogenised sand. Chlorophyll-a and chlorophyll-c concentrations were measured from the supernatant using a spectrophotometer and calculated according to equations by Jeffrey and Humphrey (1975). Concentrations are expressed as $\mu \mathrm{g}$ chlorophyll $\mathrm{g}^{-1}$ dry sediment.

\subsection{Statistical analysis}

The design was asymmetrical (i.e. having a single control group for the two factors "Butt" and "Concentration"), therefore the data were analysed by using the mean squares from two independent ANOVAs (see Green et al. (2016) for an example of the calculations). Briefly, this included partitioning of the variance by calculating (1) a one-way ANOVA with all treatments as separate levels (five treatments $\times$ six replicates each) and (2) a full-factorial twoway ANOVA of "Butt" by "Concentration" without the Control (two factors $\times$ two levels $\times$ six replicates each). The residuals of the 1st ANOVA were used to assess differences between the

171 levels within the 2nd ANOVA, allowing the variation associated with Control and that of the other treatments to be distinguished (“Control vs. Others"), which is contrasted with one degree 
of freedom (Underwood, 1997). When a significant effect in the "Control vs. Others" (C vs.

174

175

176

177

178

179

180

181

182

183

184

185

186

187

O) contrast was found, Dunnett's test was used to contrast the Control versus each level of the significant term. Post-hoc pairwise comparisons were also computed using Tukey HSD tests when the main terms in the full-factorial ANOVA were significant. Statistical significance was assumed at $\alpha=0.05$. Data were screened for normality of distribution and homogeneity of variance to check that they conformed to the assumptions of ANOVA. All statistical analyses were done using R v3.6.2. (R Core Team, 2019).

\section{Results}

3.1. Effects of cigarette butts on $\mathrm{M}$. edulis

No individuals of $M$. edulis died during the experiment. The dry biomass of M. edulis did not significantly differ amongst treatments (Tables $1 \& 2$ ). Clearance rates of $M$. edulis were significantly reduced by the addition of 1 cellulose acetate butt $\mathrm{L}^{-1}$, causing a 2.6 times reduction in clearance rates compared with $M$. edulis in the Control mesocosms or in those dosed with cellulose butts (Table 1a). The tenacity of M. edulis was not significantly affected by the addition of cigarette butts (Tables 1a and 2).

\subsection{Effects of cigarette butts on primary producers}

The growth rate of $U$. lactuca was positive in all mesocosms but was not significantly affected by cigarette butts (Tables $1 \mathrm{~b}$ and 2). Chlorophyll- $a$ content of the sediment in mesocosms exposed to 0.25 or 1 cellulose acetate butt $\mathrm{L}^{-1}$ was 2.8 times less than that of the Control mesocosms and 2.2 times less than of mesocosms with 0.25 cellulose butts $\mathrm{L}^{-1}$ (Table $1 \mathrm{~b}$, Figure 2). While mesocosms with 1 cellulose butt $\mathrm{L}^{-1}$ had less chlorophyll- $a$ than Control mesocosms, this was not significantly different (Figure 2). Chlorophyll-c content was 3.5 times less in sediment contaminated with cellulose acetate butts than in sediment with 0.25 cellulose butts $\mathrm{L}^{-1}$ (Table $1 \mathrm{~b}$ and Figure 2). 


\section{Discussion}

201 The current study found that even with constant replacement of seawater, simulating a realistic marine environment, cellulose acetate cigarette butts significantly reduced the clearance rates of $M$. edulis and the chlorophyll content of the sediment, whereas cellulose cigarette butts had minimal impact.

Clearance rates of M. edulis are used in ecotoxicity testing because they are a sensitive and ecologically relevant sub-lethal endpoint (Abel 1976). Reduced clearance rates have also been found to occur in M. edulis in response to other contaminants including mercury (Micallef and Tyler 1990), copper (Al-Subiai et al. 2011) microplastics (Woods et al. 2018) and a range of hydrophobic organic chemicals (Donkin et al. 1989). A reduction in clearance rates of these ecosystem engineers could lead to cascading effects on water quality, nutrient cycling and primary productivity in sedimentary habitats due to their role in benthic-pelagic coupling (van der Schatte et al. 2020; Barbier et al. 2011). A prolonged reduction in feeding could lead to a reduction in health causing a decrease in reproductive output and/or growth performance (Seed and Suchanek 1992). Longer term studies will help to elucidate population level implications of the results of our short-term investigation.

Although there were no measurable effects on the growth rate of U. lactuca, the concentration of chlorophyll- $a$ and $c$ of the sediment was reduced even when exposed to just 0.25 cellulose acetate butts $\mathrm{L}^{-1}$. Effects on primary producers are important since they form the base of food webs. The microphytobenthos, for example, deliver an array of vital ecosystem services including nutrient cycling, primary productivity and sediment stabilisation, and are an essential, but often overlooked, component of sedimentary habitats (Hope et al. 2019). They are also a pivotal food source for heterotrophs in sandy subtidal habitats (Evrard et al. 2012). In our study we quantified the effects on the early colonisation 
of the sediment by using clean sand as a starting point. It is also likely, however, that cigarette butts will affect established microphytobenthic communities as indicated by the recent work of Quéméneur et al. (2020) who found that leachate from cigarette butts altered established microbial communities in marine sand.

The effects on clearance rates of $M$. edulis and chlorophyll concentrations in the sediment could be due to a combination of the chemicals accumulated in the butt after smoking tobacco and the plastic itself in the cellulose acetate butts. Recently, Dilip et al. (2021) characterised 98 chemicals from smoked cigarette butt leachate, a third of which are classified as very toxic. In addition, leachate from unsmoked cellulose acetate cigarette filters has been found to be toxic to marine and freshwater fish (Slaughter et al. 2011) and to freshwater microalgae (Bonanomi et al. 2020) and unsmoked butts added as whole items have been found to decrease the germination and growth of ryegrass and clover (Green et al. 2019) and to reduce the $\mathrm{pH}$ of seawater and alter microbial communities in marine sand (Quéméneur et al. 2020). These effects could be due to plasticizers, such as diethyl phthalate, which in isolation can be toxic to plants (Cheng, 2012) and animals (Liu et al.,2009). It is possible that differences between the effects of cellulose acetate and cellulose cigarette butts in the current study were due to (i) a greater concentration of chemicals retained in cellulose acetate cigarettes after smoking, or (ii) leaching of plasticizers from cellulose acetate cigarette butts. A complete characterisation of the chemical profiles of each type of cigarette butt is needed in order to elucidate these mechanisms.

Although there was a marginal effect of 1 butt $\mathrm{L}^{-1}$ of biodegradable cellulose cigarette butts on sediment chlorophyll concentrations, there were no statistically detectable impacts on the measured responses in the current study. In a closed system, however, such as a rockpool, biodegradable cigarette butts would likely cause similar effects to non-biodegradable cigarette butts due to the retention of leachate in the water (Booth et al. 2015). Indeed, a recent 
experiment in a closed freshwater system showed that biodegradable cellulose butts had similar detrimental effects as plastic cellulose acetate butts; causing mortality and a reduction of movement of four invertebrate species (Green et al. 2020). Cigarette butts, regardless of their biodegradability, pose a threat as litter in the environment and need to be disposed of appropriately.

\section{Recommendations and conclusion}

It is likely that littering of cigarette butts occurs due to misconceptions that they are benign, i.e. having no effect on the environment and that they are rapidly biodegradable. The majority $(43 \%)$ of smokers surveyed in Germany for example, were not aware that cigarette filters are composed of synthetic material (Kotz and Kastaun 2020). Despite most cigarette butts being composed of a type of plastic, cellulose acetate, they are still not widely classified as a single use plastic. There is now evidence that cigarette butts can have detrimental effects on organisms in terrestrial (Green et al. 2019), freshwater (Green et al. 2020) and marine habitats (Booth et al. 2015, Wright et al. 2015 and the current study). To protect the environment, cellulose acetate cigarette butts should be globally classified as single-use plastics as there is urgent need to improve regulation relating to their use, collection and disposal. In addition, there needs to be an increase in campaigns to raise awareness of the impacts of cigarette litter, an increase in fines and smoking bans in areas of conservation importance (Axelsson and van Sebille, 2017) and the introduction of extended producer responsibility for tobacco companies to hold manufacturers responsible for collection, transport, processing and disposal of tobacco product waste (Curtis et al. 2017).

\section{Acknowledgements}


We would like to thank Anglia Ruskin University for granting DSG a funded sabbatical allowing her to undertake this research.

\section{References}

Abel PD. 1976. Effect of some pollutants on the filtration rate of Mytilus. Marine Pollution Bulletin, Volume 7, Issue 12, Pages 228-231, https://doi.org/10.1016/0025-326X(76)902678.

Al-Subiai SN, Moody AJ, Mustafa SA, Jha AN. 2011. A multiple biomarker approach to investigate the effects of copper on the marine bivalve mollusc, Mytilus edulis, Ecotoxicology and Environmental Safety, Volume 74, Issue 7, Pages 1913-192.

Andrady AL. 2015. In Marine Anthropogenic Litter (eds Bergmann, M., Gutow, L. \& Klages, M.) 57-72 (Springer, Cham, 2015).

Amos C, Allred A, Zhang L. 2017. Do Biodegradable Labels Lead to an Eco-safety Halo Effect? J Consum Policy 40, 279-298.

Araújo MCB, Costa MF. 2019. A critical review of the issue of cigarette butt pollution in coastal environments. Environmental Research, 172: 137-149.

Axelsson C, van Sebille E. Prevention through policy: Urban macroplastic leakages to the marine environment during extreme rainfall events. Mar Pollut Bull. 2017;124(1):211-227. doi:10.1016/j.marpolbul.2017.07.024

Barbier EB, Hacker SD, Kennedy C, Koch EW, Stier AC, Silliman BR. 2011. The value of estuarine and coastal ecosystem services. Ecol. Monogr., 81 (2) (2011), pp. 169-193.

Bell EC, Gosline JM. 1997. Strategies for life inflow: tenacity, morphometry, and probability of dislodgment of two Mytilus species. Marine Ecology Progress Series, 10.3354/meps159197.

Booth DJ, Gribben P, Parkinson K. 2015. Impact of cigarette butt leachate on tidepool snails. Marine Pollution Bulletin, 15, 95(1):362-4.

Bonanomi G, Maisto G, De Marco A, Cesarano G, Zotti M, Mazzei P, Libralato G, Staropoli A, Siciliano A, De Filippis F, La Storia A, Piccolo A, Vinale F, Crasto A, Guida M, Ercolini D, Incerti G. 2020. The fate of cigarette butts in different environments: Decay rate, chemical changes and ecotoxicity revealed by a 5-years decomposition experiment. Environmental Pollution, Volume 261,114108.

Cheng S. 2012. The toxic effects of diethyl phthalate on the activity of glutamine synthetase in greater duckweed (Spirodela polyrhiza 1.). Aquat. Toxicol. 124-125, 171-178.

Chevalier Q, Hadri HE, Petitjean P, Le Coz MB, Reynaud S, Grassl B, Gigault J. 2018. Nano-litter from cigarette butts: Environmental implications and urgent consideration, Chemosphere, 194: 125-130. 
Consoli P, Scotti G, Romeo T, Fossi MC, Esposito V, D'Alessandro M, Battaglia P, Galgani F, Figurella F, Pragnell-Raasch H, Andaloro F. 2020. Characterization of seafloor litter on Mediterranean shallow coastal waters: Evidence from Dive Against Debris ${ }^{\circledR}$, a citizen science monitoring approach, Marine Pollution Bulletin, Volume 150.

Curtis C, Novotny TE, Lee K, Freiberg M, McLaughlin I. 2017. Tobacco industry responsibility for butts: a Model Tobacco Waste Act. Tobacco Control: 26:113-117.

Dilip V, Hanna SK, Gagliano GG, Chang HW. 2021. No Butts on the Beach: Aquatic Toxicity of Cigarette Butt Leachate Chemicals. Tobacco Regulatory Science 7(1):17-30.

Donkin P, Widdows J, Evans SV, Worrall CM, Carr M. 1989. Quantitative structure-activity relationships for the effect of hydrophobic organic chemicals on rate of feeding by mussels (Mytilus edulis), Aquatic Toxicology, Volume 14, Issue 3, Pages 277-293.

Dobaradaran S, Schmidt TC, Lorenzo-Parodi N, Jochmann MA, Nabipour I, Raeisi A, Stojanović N, Mahmoodi M. 2019. Cigarette butts: An overlooked source of PAHs in the environment? Environmental Pollution, 249: 932-939.

\section{Evrard V, Huettel M, Cook PLM, Soetaert K, Heip CHR, Middelburg JJ (2012) Importance} of phytodetritus and microphytobenthos for heterotrophs in a shallow subtidal sandy sediment. Mar Ecol Prog Ser 455:13-31

GBD 2015 Tobacco Collaborators. 2017. Smoking prevalence and attributable disease burden in 195 countries and territories, 1990-2015: a systematic analysis from the Global Burden of Disease Study 2015, The Lancet, Volume 389, Issue 10082, Pages 1885-1906,

Gerritse J, Leslie HA, de Tender CA, Devriese LI, Vethaak AD. 2020. Fragmentation of plastic objects in a laboratory seawater microcosm. Scientific Reports, 10(1):10945. doi:10.1038/s41598-020-67927-1.

Green DS, Boots B, Da Silva Carvalho J, Starkey T. 2019. Cigarette butts have adverse effects on initial growth of perennial ryegrass (gramineae: Lolium perenne L.) and white clover (leguminosae: Trifolium repens L.),Ecotoxicology and Environmental Safety, Volume $182,2019,109418$.

Green DS, Kregting L, Boots B. 2020. Smoked cigarette butt leachate impacts survival and behaviour of freshwater invertebrates. Environmental Pollution, Volume 266, Part 3, 115286. https://doi.org/10.1016/j.envpol.2020.115286.

Hope JA, Paterson DM, Thrush SF. 2019. The role of microphytobenthos in soft-sediment ecological networks and their contribution to the delivery of multiple ecosystem services. Journal of Ecology,

Kungskulniti N, Charoenca N, Hamann SL, Pitayarangsarit S, Mock J. 2018. Cigarette Waste in Popular Beaches in Thailand: High Densities that Demand Environmental Action. Int. J. Environ. Res. Public Health, 15, 630.

Kotz D, Kastaun S. 2020. Do people know that cigarette filters are mainly composed of synthetic material? A representative survey of the German population (the DEBRA study) Tobacco Control Published. doi: 10.1136/tobaccocontrol-2019-055558 
Lawal MS, Ologundudu SO. 2013. Toxicity of cigarette filter leachates on Hymenochirus curtipes and Clarias gariepinus in Nigeria. J Environ Ext 11:7-14.

Loizidou XI, Loizides MI, Orthodoxou DL. 2018. Persistent marine litter: small plastics and cigarette butts remain on beaches after organized beach cleanups. Environ Monit Assess 190, 414.

Liu Y, Guan Y, Yang Z. 2009. Toxicity of seven phthalate esters to embryonic development of the abalone Haliotis diversicolor supertexta. Ecotoxicology 18, 293-303. https://doi.org/10.1007/s10646-008-0283-0.

Micallef S, Tyler PA. 1990. Effect of mercury and selenium on the gill function of Mytilus edulis, Marine Pollution Bulletin, Volume 21(6): 288-292.

Moerman JW, Potts GE. 2011. Analysis of metals leached from smoked cigarette litter. Tobacco Control, 20: 30-35.

Ocean Conservancy. 2019. The beach and beyond: international coastal clean-up 2019 report. Available from https://oceanconservancy.org. accessed 15/05/2020.

Pascoe PL, Parry HE, Hawkins AJS. 2009. Observations on the measurement and interpretation of clearance rate variations in suspension-feeding bivalve shellfish. Aquat Biol 6:181-190. https://doi.org/10.3354/ab00123

Patel V, Thomson GW, Wilson N. 2013. Cigarette butt littering in city streets: a new methodology for studying and results. Tob. Control, 22: 59-62

Pauly JL, Mepani AB, Lesses JD, Cummings KM, Streck RJ. 2002. Cigarettes with defective filters marketed for 40 years: what Philip Morris never told smokers. Tob Control. 2002 Mar;11 Suppl 1:I51-61.

Peeken, I., Primpke, S., Beyer, B. et al. Arctic sea ice is an important temporal sink and means of transport for microplastic. Nat Commun 9, 1505 (2018). https://doi.org/10.1038/s41467-018-03825-5

Plastics Europe. 2019. Seabin, a new kind of floating bin. Plastics Le Mag - Innovation and Plastics Magazine. Website: http://plastics-themag.com/Seabin-a-new-kind-of-floating-bin. Accessed $18^{\text {th }}$ May 2020.

Quéméneur M, Chifflet S, Akrout F, Bellaaj-Zouari A, Belhassen M. 2020. Impact of cigarette butts on microbial diversity and dissolved trace metals in coastal marine sediment. Estuarine, Coastal and Shelf Science, 240: 106785.

R Core Team. 2019 R: A language and environment for statistical computing. R Foundation for Statistical Computing. Vienna, Austria. URL https://www.R-project.org/.

Rath JM, Rubenstein RA, Curry LE, Shank SE, Cartwright JC. 2012. Cigarette Litter: Smokers' Attitudes and Behaviors. Int. J. Environ. Res. Public Health 9, 2189-2203.

Rech S, Macaya-Caquilpán V, Pantoja JF, Rivadeneira MM, Jofre Madariaga D, Thiel M. 2014. Rivers as a source of marine litter - A study from the SE Pacific, Marine Pollution Bulletin, Volume 82(1-2): 66-75. 
Roder Green AL, Putschew A, Nehls T. 2014. Littered cigarette butts as a source of nicotine in urban waters. Journal of Hydrology, 519: 3466-3474.

$$
\text { Rodríguez C, Fossatti M, Carrizo D, Sánchez-García L, de Mello, FT Weinstein F, Lozoya }
$$
JP. 2020. Mesoplastics and large microplastics along a use gradient on the Uruguay Atlantic coast: Types, sources, fates, and chemical loads. Science of The Total Environment, 721: 137734.

Roman L, Hardesty BD, Leonard GH, Pragnell-Raasch H, Mallos N, Campbell I, Wilcox C. 2020. A global assessment of the relationship between anthropogenic debris on land and the seafloor, Environmental Pollution, 264: 114663.

Seed R, Suchanek TH. 1992. Population and community ecology of Mytilus. In E. Gosling (Ed.), The mussel Mytilus: Ecology, physiology, genetics and culture (pp. 87-169). Elsevier.

Slaughter E, Gersberg RM, Watanabe K, Rudolph J, Stransky C, Novonty TE. 2011. Toxicity of cigarette butts, and their chemical components, to marine and freshwater fish. Tobac. Contr., 20 (1), pp. 25-29

The Seabin Project. 2020. Website: https://seabinproject.com/the-seabin-v5/. Accessed $18^{\text {th }}$ May 2020.

Woods MN, Stack ME, Fields DM, Shaw SD, Matrai PA. 2018. Microplastic fiber uptake, ingestion, and egestion rates in the blue mussel (Mytilus edulis), Marine Pollution Bulletin, Volume 137, Pages 638-645, https://doi.org/10.1016/j.marpolbul.2018.10.061.

van der Schatte O, Jones A, Vay L, Christie LL, Wilson M, Malham S.K. 2020. A global review of the ecosystem services provided by bivalve aquaculture. Rev Aquacult, 12: 3-25. doi:10.1111/raq.12301

World Health Organization. 2019. WHO report on the global tobacco epidemic, 2019: monitoring tobacco use and prevention policies. Geneva, Switzerland: World Health Organization. 


\section{Tables and figures}

Table 1. Asymmetrical ANOVA results for (a) tenacity (Tenacity), dry weight (DW) and clearance rates of M. edulis (Clearance rates) and (b) growth of $U$. lactuca (Ulva growth), chlorophyll- $a$ or $-c$ content of the sediment (Chl- $a$, Chl-c). F ratios with P-values significant at $\alpha=0.05$ are indicated in bold. MPB Chl- $a$ and MPB Chl- $c$ were square root and $\log (\mathrm{x}+0.5)$ transformed respectively in order to meet the assumption of normality of distribution.

\begin{tabular}{|c|c|c|c|c|c|c|c|c|c|c|}
\hline \multicolumn{2}{|l|}{ (a) } & \multicolumn{3}{|c|}{ Tenacity } & \multicolumn{3}{|c|}{ DW } & \multicolumn{3}{|c|}{ Clearance rates } \\
\hline Source of variation & d.f. & MS & F-ratio & P-value & MS & F-ratio & P-value & MS & F-ratio & P-value \\
\hline One-way & 4 & 0.02 & 0.57 & 0.686 & 0.01 & 0.62 & 0.651 & 23.94 & 4.75 & 0.005 \\
\hline Control vs others & 1 & 0.03 & 0.82 & 0.374 & 0.00 & 0.42 & 0.521 & 21.80 & 4.32 & 0.048 \\
\hline Butt (B) & 1 & 0.01 & 0.18 & 0.679 & 0.01 & 1.00 & 0.327 & 11.29 & 2.24 & 0.147 \\
\hline Concentration (C) & 1 & 0.03 & 0.77 & 0.389 & 0.01 & 0.70 & 0.410 & 23.44 & 4.65 & 0.041 \\
\hline $\mathrm{B} \times \mathrm{C}$ & 1 & 0.02 & 0.52 & 0.477 & 0.00 & 0.37 & 0.551 & 39.23 & 7.78 & 0.010 \\
\hline \multicolumn{2}{|l|}{ (b) } & \multicolumn{3}{|c|}{ Ulva growth } & \multicolumn{3}{|c|}{ MPB Chl-a } & \multicolumn{3}{|c|}{ MPB Chl-c } \\
\hline Source of variation & d.f. & MS & F-ratio & P-value & MS & F-ratio & P-value & MS & F-ratio & P-value \\
\hline One-way & 4 & 6.21 & 1.29 & 0.299 & 0.26 & 4.71 & 0.006 & 0.49 & 2.97 & 0.039 \\
\hline Control vs others & 1 & 5.11 & 1.06 & 0.312 & 0.30 & 5.77 & 0.024 & 0.35 & 2.50 & 0.127 \\
\hline Butt (B) & 1 & 6.66 & 1.39 & 0.250 & 0.43 & 7.86 & 0.010 & 0.94 & 6.45 & 0.018 \\
\hline Concentration (C) & 1 & 9.55 & 1.99 & 0.171 & 0.18 & 3.89 & 0.060 & 0.35 & 1.66 & 0.210 \\
\hline $\mathrm{B} \times \mathrm{C}$ & 1 & 3.51 & 0.73 & 0.400 & 0.10 & 1.30 & 0.264 & 0.30 & 1.27 & 0.271 \\
\hline
\end{tabular}


Table 2. Tenacity $\left(\mathrm{N} \mathrm{cm}^{-2}\right)$ and dry weight of flesh (g) for M. edulis and growth (g) of $U$. lactuca after exposure to either no butts (Control) or to 0.25 or 1 butt $\mathrm{L}^{-1}$ of smoked cellulose $(\mathrm{C})$ or cellulose acetate $(\mathrm{CA})$ cigarette butts. Data are mean \pm S.E.M., $\mathrm{n}=6$.

\begin{tabular}{llll}
\hline Response / Treatment & Tenacity $(\mathrm{N})$ & Dry weight flesh $(\mathrm{g})$ & U. lactuca absolute growth $(\mathrm{g})$ \\
\hline Control & $2.2 \pm 0.6$ & $0.32 \pm 0.04$ & $5.69 \pm 0.95$ \\
C 0.25 butts $\mathrm{L}^{-1}$ & $1.6 \pm 0.3$ & $0.37 \pm 0.05$ & $4.38 \pm 0.66$ \\
C 1 butt L & $1.8 \pm 0.3$ & $0.37 \pm 0.03$ & $3.89 \pm 0.56$ \\
CA 0.25 butts L-1 & $0.3 \pm 0.1$ & $0.30 \pm 0.04$ & $6.20 \pm 0.92$ \\
CA 1 butt L-1 & $0.2 \pm 0.1$ & $0.36 \pm 0.05$ & $4.18 \pm 1.23$ \\
\hline
\end{tabular}




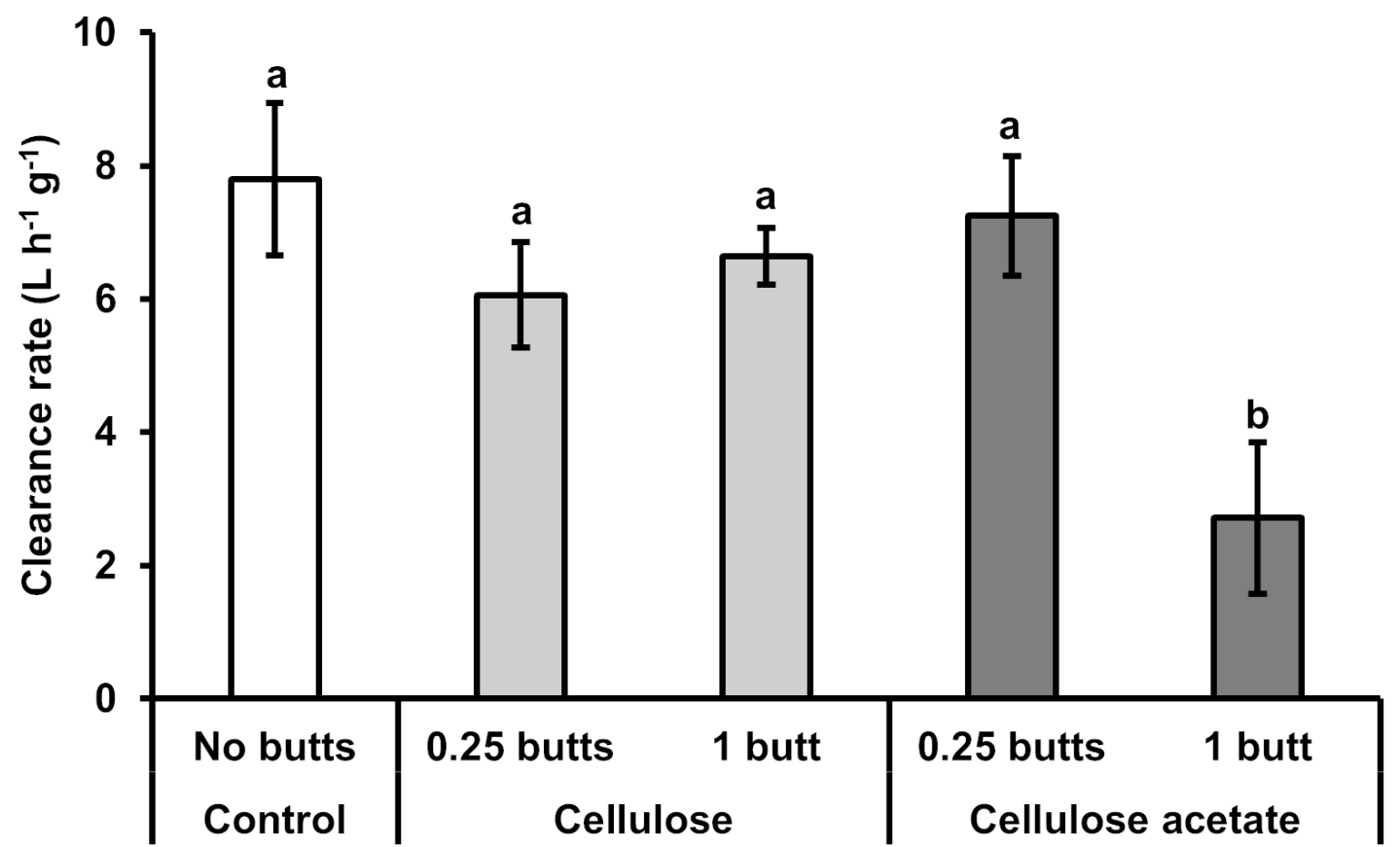

Figure 1. Clearance rates of M. edulis exposed to no butts or to smoked cellulose or smoked cellulose acetate cigarette butts at 0.25 or 1 butt $\mathrm{L}^{-1}$. Data are mean \pm S.E.M. based on dry weight, $\mathrm{n}=6$. Different superscript letters indicate a significant difference at $\alpha=0.05$. 

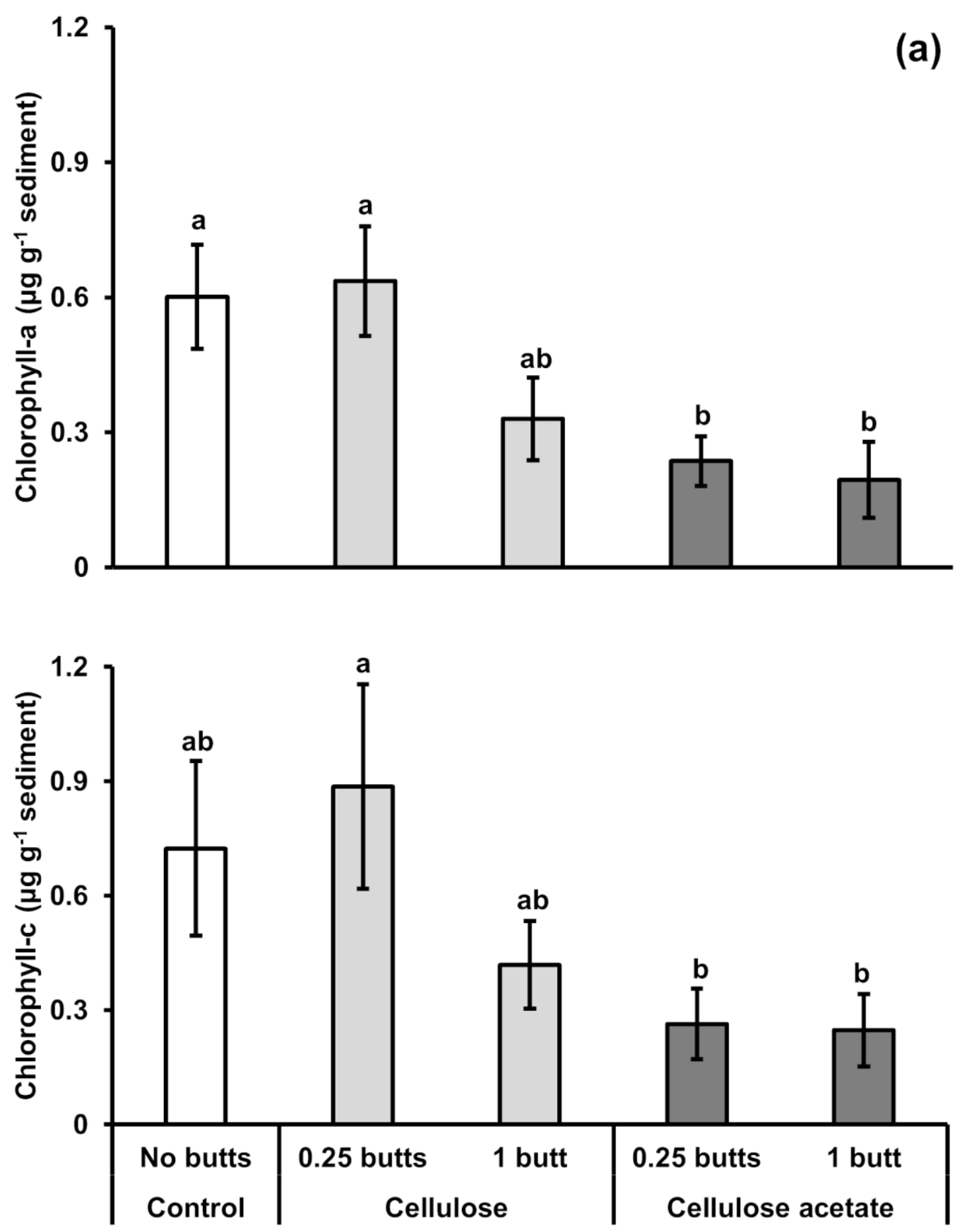

Figure 2. Chlorophyll- $a$ (a) and chlorophyll- $c$ (b) content extracted from sand exposed to either no butts (Control), smoked cellulose or smoked cellulose acetate butts at 0.25 or 1 butt $\mathrm{L}^{-1}$. Data are mean \pm S.E.M. based on dry sediment, $\mathrm{n}=6$. Different superscript letters indicate a significant difference at $\alpha=0.05$. 